The main advantage of this apparatus is the treatment of contaminated materials inside hospital wards, at the point of initial collection, by nonspecialized staff. As it works without grinding, no potentially infectious particles are suspended in the air during the treatment. The pancakes produced are solid and easy to manipulate. After treatment, waste can be eliminated as household rubbish in classic incinerators. The cost of this final treatment is much lower than the cost of incineration of infectious waste. Finally, this apparatus is both a waste disinfection and disposal system that avoids hazardous transport from the point of initial collection to the incinerator. Nevertheless, it is necessary to promote separation between contaminated and nonhazardous hospital waste that requires no special handling and disposal. It would be helpful to implement a program for reducing biomedical waste, including reviewing waste practices, educating staff, ${ }^{25}$ and redefining infectious waste (the small proportion of medical waste that could potentially transmit an infectious disease) ${ }^{26}$

Despite the lack of association between dissemination of microorganisms from clinical waste and the development of infectious diseases, machines like Dipsys 25 are necessary to avoid such risk and to conform to legislation.

\section{REFERENCES}

1. Rutala WA, Mayhall CG. Medical waste. Infect Control Hosp Epidemiol 1992;13:38-48.

2. Phillips G. Microbiological aspects of clinical waste. J Hosp Infect 1999;41:1-6.

3. Collins $\mathrm{CH}$, Kennedy DA. The microbiological hazards of municipal and clinical wastes. $J$ Appl Bacteriol 1992;73:1-6.

4. Keene JH. Medical waste: a minimal hazard. Infect Control Hosp Epidemiol 1991;12:682-685.

5. Daschner F. The hospital and pollution: role of the hospital epidemiologist in protecting the environment. In: Wenzel RP, ed. Prevention and Control of Nosocomial Infections. 3rd ed. Baltimore, MD: Williams \& Wilkins; 1997:595-605.

6. Blenkharn JI. The disposal of clinical wastes. J Hosp Infect 1995;30(suppl):514-520.

7. Bencko V, Culikova H. Hospital waste management practice in the Czech Republic. Cent Eur J Public Health 1993;1:57-59.

8. Liss GM, Crimi C, Jaczek KH, Anderson A, Slattery B, D'Cunha C. Improper office disposal of needles and other sharps: an occupational hazard outside of health care institutions. Can J Public Health 1990;81:417-420.

9. Springthorpe VS, Kennedy ME. Infect Control Steriliz Technol 1998;4:38-43.

10. Association Française de Normalisation (AFNOR). Antiseptiques et désinfectants utilisés à l'état liquide miscibles à l'eau et neutralisables: détermination de l'activité bactéricide en présence de substances interférentes de référence. NFT 72-170. Paris, France: Association Française de Normalisation; 1988.

11. Association Française de Normalisation (AFNOR). Antiseptiques et désinfectants: conservation et contrôle des souches bactériennes utilisées pour la détermination de l'activité bactéricide. NFT 72-140. Paris, France: Association Française de Normalisation; 1988.

12. Association Française de Normalisation (AFNOR) Antiseptiques et désinfectants utilisés à l'état liquide, miscibles à l'eau et neutralisables: détermination de l'activité sporicide. NFT 72-230. Paris, France: Association Francaise de Normalisation; 1988.

13. Association Française de Normalisation (AFNOR). Désinfectant de contact utilisés à l'état liquide, miscibles à l'eau; détermination de l'activité bactéricide, sporicide et fongicide par la méthode des portegermes. NFT 72-190. Paris, France: Association Française de Normalisation; 1988.

14. The Hospital Infection Society. Disinfection in washing machines.J Hosp Infect 1983;4:101-102.

15. Pleus RC, Kelly KE. Health effects from hazardous waste incineration facilities: five case studies. Toxicol Ind Health 1996;12:277-287.

16. Blenkharn JI, Oakland D. Emission of viable bacteria with the exhaust flue gases from hospital incinerators. J Hosp Infect 1989;14:73-78.

17. Scott GM, Jones GH. Emission of a viable bacteria in the exhaust flue from a waste incinerator. J Hosp Infect 1990;16:183-184.

18. Goldblith SA, Wang DIC. Effect of microwaves on Escherichia coli and Bacillus subtilis. Appl Microbiol 1967;17:106-110.

19. Lechowich RV, Beuchat LR, Fox KI, Webster FH. Procedures for evaluating the effects of 2,450 megahertz microwaves upon Streptococcus faecalis and Saccharomyces cerevisiae. Appl Microbiol 1969;17:106-110.

20. Vela GR, Wu JF. Mechanism of lethal action of 2,450 Mhz radiation on microorganisms. Appl Environ Microbiol 1979:37:550-553.

21. Najdowski L, Dragas AZ, Kotnik V. The killing activity of microwaves on some non-sporogenic and sporogenic medically important bacterial strains. J Hosp Infect 1991;19:239-247.

22. Jeng DKH, Kaczmarek KA, Woodworth AG, Balasky G. Mechanisms of microwave sterilization in the dry state. Appl Environ Microbiol 1987;53:2133-2137.

23. Furia L, Hill DW, Gandhi OP. Effect of milimetre-wave irradiation on growth of Saccharomyces cerevisiae. IEEE Trans Biomed Engineer 1986;33:993-999.

24. Fujikawa H, Ushioda H, Kudo Y. Kinetics of Escherichia coli destruction by microwave irradiation. Appl Environ Microbiol 1992;58:920-924.

25. Escaf M, Shurtleff S. A program for reducing biomedical waste: the Wellesley Hospital experience. Can J Infect Control 1996;11:7-11.

26. Rutala WA. Disinfection, sterilization and waste disposal. In: Wenzel RP, ed. Prevention and Control of Nosocomial Infections. 3rd ed. Baltimore, MD: Williams \& Wilkins; 1997:539-593.

\title{
Risk Factors for Persistent Carriage of MRSA
}

Gina Pugliese, RN, MS

Martin S. Favero, PhD

Harbarth and colleagues, from the University Hospitals of Geneva, Switzerland, determined risk factors associated with persistent carriage of methicillin-resistant Staphylococcus aureus (MRSA) among 102 patients enrolled in a double-blinded, placebo-controlled trial of nasally administered mupirocin ointment. MRSA decolonization was unsuccessful in $77(79 \%)$ of 98 patients who met the criteria for evaluation.
By univariate analysis, four variables were found to be associated with persistent MRSA colonization $(P<.1$ for all 4$)$ : absence of mupirocin treatment, previous fluoroquinolone therapy, $\geqslant 2$ MRSA-positive body sites, and low-level mupirocin resistance. After multivariable Cox proportional hazards modeling, the presence of $\geqslant 2$ positive body sites (adjusted hazard ratio [AHR], $1.7 ; 95 \%$ confidence interval $\left[\mathrm{CI}_{95}\right], 1.0-2.9$ ) and previous receipt of a fluoroquinolone (AHR, 1.8; $\left.\mathrm{CI}_{95}, 1.0-3.3\right)$ were independently associated with MRSA persistence, whereas nasal mupirocin tended to confer protec- tion (AHR, 0.6; $\mathrm{CI}_{95}, 0.4-1.0$ ). Low-level mupirocin resistance was observed in nine genotypically different MRSA strains and was not independently associated with chronic MRSA carriage (AHR, $1.5 ; \mathrm{CI}_{95}, 0.9$ 2.5). These findings suggest that multisite MRSA carriage and previous receipt of a fluoroquinolone are independent risk factors for persistent MRSA colonization.

FROM: Harbarth S, Liassine N, Dharan S, Herrault P, Auckenthaler R, Pittet $D$. Risk factors for persistent carriage of methicillin-resistant Staphylococcus aureus. Clin Infect Dis 2000;31:1380-1385. 